\title{
Uji Resistensi Primer Mycobacterium tuberculosis terhadap INH (Isonicotinyl ydrazide) Pada Penderita Tuberculosis
}

\author{
Vania Claudy Rara Rante Allo ${ }^{1}$, Mursalim² \\ 1,2 Jurusan Analis Kesehatan Poltekkes Kemenkes Makassar
}

Koresponden: mursalim@ poltekkes-mks.ac.id/081316091968

\begin{abstract}
ABSTRAK
Jumlah penderita TB berdasarkan data yang diperoleh dari Balai Besar Kesehatan Paru Masyarakat di Makassar pada tahun 2010, jumlah kasus TB adalah 4944 dan pada tahun 2011 dari bulan januari sampai bulan November adalah 5368. Dari data BBKPM Makassar pada tahun 2017 suspek penderita TB MDR berjumlah 2224 pasien dan penderita TB MDR berjumlah 24 pasien. Teknik pengambilan sampel menggunakan Purposive sampling cara dengan ciri - ciri yang ditetapkan sampai jumlah kuota yang telah ditentukan tercukupi. Jenis penelitian ini adalah penelitian observasi laboratorik yang bersifat deskriptif, yang bertujuan untuk mengetahui hasil deteksi resistensi primer Mycobacterium tuberculosis terhadap INH (Isonicotinyl hydrazide) pada penderita tuberkulosis yang baru memulai pengobatan dengan metode PCR. Hasil penelitian menunjukkan bahwa, dari 13 sampel yang diamplifikasi, didapatkan $4(31 \%)$ sampel sputum penderita Tuberkulosis yang baru memulai pengobatan resisten terhadap INH dan 9 (69\%) sampel sputum penderita Tuberkulosis yang baru memulai pengobatan sensitive terhadap INH dan terjadinya resistensi Mycobacterium tuberculosis terhadap INH dipengaruhi oleh mutasi pada beberapa gen, mutasi ini terutama terjadi pada gen katG, gen inhA, dan gen ahpC.
\end{abstract}

Kata Kunci : Mycobacterium tuberculosis, Resistensi Primer, INH, Penderita Tuberkulosis

\section{PENDAHULUAN}

Program penanggulangan TB paru secara nasional mengacu pada strategi DOTS (Directly Observed Treatment Shortcouse) yang di rekomendasikan oleh WHO, dan terbukti dapat memutus rantai penularan TB paru. Penderita TB hendaknya diberikan OAT (Obat Anti Tuberkulosis) kombinasi yang tepat dengan pemeriksaan sputum yang teratur. Untuk penderita yang belum resisten terhadap OAT diberikan regimen selama 6 bulan yang terdiri dari isoniazid (INH), rifampin (RIF) dan pyrazinamide (PZA) selama 2 bulan kemudian diikuti dengan INH dan PZA selama 4 bulan. Pengobatan inisial dengan 4 macam obat termasuk Etambutanol (EMB) dan Streptomisin diberikan jika infeksi TB terjadi di daerah dengan peningkatan prevalensi resistensi terhadap INH (Masriadi, 2014).

Salah satu alasan gagalnya program pengendalian TB dinegara berkembang karena kelemahan diagnostik untuk mendeteksi kasus infeksi pada saat dini. Pada umumnya metode diagnostic penyakit TB dilakukan secara konvensional seperti pemeriksaan mikroskopik, kultur dan serologi. Namun, metode tersebut mempunyai 
banyak kelemahan. Pemeriksaan mikroskopik disamping memerlukan kuman/bakteri minimal $10.000 \mathrm{sel} / \mathrm{ml}$, juga tidak dapat mendeteksi spesies mikobakteria. Pemeriksaan kultur kuman mempunyai sensitivitas dan spesifisitas cukup tinggi, akan tetapi memerlukan waktu yang cukup tinggi, akan tetapi memerlukan waktu yang cukup tinggi, akan tetapi memerlukan waktu yang lama yang berkisar 3-8 minggu. Sensitivitas metode tersebut mendekati 100\% dan dapat dilakukan pada sampel klinis yang mempunyai kandungan bakter 10-100 sel. Metode PCR adalah metode yang cepat, sensitif dan spesifik jika dibandingkan dengan kulur untuk memeriksa resistensi. (Rosilawati dkk, 2002).

Hasil penelitian Dyan Kunthi Nugrahaen (2013) tentang analisis penyebab resistensi obat $\mathrm{TB}$ didapatkan hasil dari 26 responden yang resisten OAT sebanyak 10 orang ( $38,5 \%$ ) mengalami resisten obat kombinasi R,H ( Rifampisin dan Isoniazid), resisten kombinasi R,H,E,dan S ( Rifampisin, Isoniazid, Erhambutanol, Streptomisin ) sebanyak 4 orang $(15,4 \%)$ dan resistensi sebagian besar jenis OAT yang efektif melawan Mycobacterium tuberculosis yang resisten kombinasi obat R,H,Z,E,S dan K (Rifampisin ,Isoniazid ,Pirazinamid, Erhambutano 1, Streptomisin dan Kanamisin) sebanyak 4 orang $(11,6 \%)$.

Akibat dampak dari peningkatan MDR-TB dan relative terbatasnya jumlah agen terapeutik yang ada, maka dilakukan upaya untuk menentukan dasar molekuler resistensi Mycobacterium tuberculosis terhadap OAT. Agar segera diketahui dan penderita dapat diterapi dengan pengobatan yang sesuai secara cepat dan tepat. Sampai saat ini belum diketahui dengan jelas dan pasti resistensi primer Mycobacterium tuberculosis terhadap INH pada penderita TB yang baru memulai pengobatan.

Berdasarkan uraian diatas maka perlu dilakukan penelitian tentang resistensi primer Mycobacterium tuberculosis terhadap INH pada penderita TB yang baru memulai pengobatan dengan metode PCR. Bertujuan untuk mengetahui resistensi primer Mycobacterium tuberculosis terhadap INH (Isonicotinyl hydrazide) pada penderita tuberkulosis dengan metode PCR

\section{METODE}

\section{Jenis Penelitian, Lokasi dan Waktu}

Jenis penelitian ini adalah penelitian observasi laboratorik yang bersifat deskriptif, yang bertujuan untuk mengetahui hasil deteksi resistensi primer Mycobacterium tuberculosis terhadap INH (Isonicotinyl hydrazide) pada penderita tuberkulosis yang baru memulai pengobatan dengan metode PCR. Tempat penelitian ini dilaksanakan di Balai besar Paru Kesehatan Masyarakat Makassar dan Hum-RC Universitas Hasanuddin. Waktu penelitian dilaksanakan pada bulan Februari - Maret 2019.

\section{Jumlah Sampel, Teknik Pengambilan Sampel, Alat dan Bahan Penelitian}

Dalam penelitian ini adalah penderita tuberkulosis paru dengan konfirmasi BTA (+) dan berdasarkan observasi $20-30$ sampel per bulan. Sampel penderita tuberkulosis yang baru mulai pengobatan dengan jumlah sebanyak 13 sampel. Teknik pengambilan sampel menggunakan Purposive sampling cara dengan ciri - 
ciri yang ditetapkan sampai jumlah kuota yang telah ditentukan tercukupi .

Alat yang akan digunakan dalam penelitan ini adalah pot dahak, kantong plastik dengan pengaman (Clipped), pipet dengan bulb,tabung ulir, lampu spiritus, tabung Sentrifus $50 \mathrm{ml}$, rak tabung, biocontained - centrifuge pada gaya gravitasi $3000 \mathrm{~g}$ (bukan $3000 \mathrm{rpm}$ ), pipet pasteur steril atau mikropipet 100 $\mu 1$, tip mikropipet, inkubator, BSC Class II, tabung Eppendorf, mikropipet 1-100 $\mu \mathrm{l}$, clinipet $100 \mu \mathrm{l}$ (pipette $100 \mu \mathrm{l}$ ), sentrifuge, tip, tabung, water bath, oven rotary shaker, vortex, tip aerosol $1000 \mu 1$, $100 \mu \mathrm{l}$, dan $10 \mu \mathrm{l}$, thermocycler, laminary flow, tube/vial $0.5 \mathrm{ml}$ dan 1,5 $\mathrm{ml}$, mikropipet + tip filter, DNA thermalcycler (hybaid, OMN - E ), elektroforesis + tip supply, alat PCR, botol reagen, mesin translimunator UV, neraca analitik, sendok tanduk, pesawat $\mathrm{x}$ - ray immunoassay, refrigerator, chamber, comb, microwave. Bahan yang digunakan adalah sampel sputum, bahan pengawet cetyl piridinium chloride (CPC) 1\%, media LJ, \%, media LJ, alkohol $70 \%$, proteinase K, $10 \%$ SDS, NaCL 5 M, fenol, CIAA, etanol absolut, buffer TE ,marker, loading beuffer, agarose (smart ladder SF), pure destiled water (baker), Primer yang digunakan : katG0-F

(5'CAGATGGGGCTGATCTACG-3'), katG315-R

(5'CCATACGACCTCGATGCCGC-3'), ahpC-46

(5'ATGCCGATAAATATGGTGTG-3'), ahpC-R

(5'GCGAATTCGCTGTCAATCGA-3'), inhA-F

(5'AATTGCGCGGTCAGTTCCACAC3'), inhA-R

(5'CACCCCGACAACCTATCG-3')

PCR masker mix green (terdiri dari enzim, taq polymerase, dNTP, buffer, $\mathrm{MgCl}$ ), Buffer Tris - asam borat (TBE): $89 \mathrm{mM}$ Tris - Cl: $89 \mathrm{mM}$ borat: dan 2 mM larutan EDTA, loading dye: $0.4 \%$ bromo-phenol blue, $50 \%$ gliserol, $1 \mathrm{mM}$ EDTA pH 8, etidium bromide, DNA, gel agarose.

\section{Jenis dan Cara Pengumpulan Data}

Cara Pengumpulan Sputum berdasarkan Kemenkes RI, 2012 cara pengumpulan sputum adalah : Pasien diberitahu bahwa contoh uji dahak sangat bernilai untuk menentukan status penyakitnya, karena itu anjuran pemeriksaan SPS untuk pasien baru dan SP untuk pasien dalam pemantauan pengobatan harus dipenuhi. Persiapan alat yaitu pot sputum bersih dan kering, diameter mulut pot $4-5 \mathrm{~cm}$, transparan, bening, tertutup ulir. Pot tidak boleh bocor. Sebelum diserahkan kepada pasien, pot sputum harus sudah diberi identitas sesuai identitas / nomor register pada form TB. Dilanjutkan dengan pemeriksaan kultur dengan larutan dekontaminasi $(\mathrm{NaOH} 4 \%+$ Sodium citrate $2,9 \%+\mathrm{N}$-Acetyl L-Cystein) dengan volume perbandingan yang sama (1:1). Selanjutnya divortex selama 10 detik, lalu dibiarkan selama 15 menit pada suhu kamar. Kemudian ditambahkan Phospat Buffer Saline (PBS) Ph 6,8 hingga volume mencapai $50 \mathrm{ml}$, lalu disentrifugasi $3000 \mathrm{~g}$ selama 15 menit. Supernatant dibuang secara perlahan dan endapan/ pellet ditambahkan 1 - 2 ml PBS. Selanjutnya hasil dekontaminasi ini digunakan untuk kultur. Selanjutnya kultur pada media padat loweinstein Jensen. Kemudian diisolasi DNA metode Chelex. Selanjutnya dideteksi DNA TB dengan single PCR. 


\section{Analisa Data}

Data dianalisa secara deskriptif dengan memaparkan hasil akhir pemeriksaan adanya resistensi primer Mycobacterium tuberculosis terhadap INH (Isonicotinyl hydrazide) pada penderita tuberkulosis yang baru memulai pengobatan dengan metode PCR dan dibahas dalam bentuk Narasi.

\section{HASIL}

Hasil penelitian menunjukkan bahwa, dari 13 sampel yang diamplifikasi, didapatkan 4 (31\%) sampel sputum penderita Tuberkulosis yang baru memulai pengobatan resisten terhadap INH dan 9 (69\%) sampel sputum penderita Tuberkulosis yang baru memulai pengobatan sensitive terhadap INH dan terjadinya resistensi Mycobacterium tuberculosis terhadap INH dipengaruhi oleh mutasi pada beberapa gen, mutasi ini terutama terjadi pada gen katG, gen inhA, dan gen ahpC.

\section{PEMBAHASAN}

Resistensi terhadap obat anti tuberkulosis dapat berupa : Mono Resisten adalah terdapatnya resistensi terhadap 1 macam obat anti tuberkulosis , Multi Drug Resisten ( MDR ) adalah terdapatnya resistensi terhadap minimal 2 macam obat anti tuberkulosis yatu INH dan rifampisin dengan atau tanpa obat anti tuberkulosis lainnya, Poli Resisten adalah terdapatnya resistensi terhadap lebih dari 1 obat anti tuberkulosis tapi bukan kombinasi INH dan rifampisin. Metode PCR digunakan untuk mendeteksi adanya mutasi pada gen inhA, gen katG, dan gen ahpC, sebagai penanda terjadinya resistensi INH. Gambaran hasil diagnostic dengan teknik PCR tersebut menunjukkan bahwa bakteri dapat menjadi resisten terhadap antbotik yang sebelumnya efektif. Kemampuan bakteri tersebut untuk terus menerus menembangakan resistensi terhadap agen antibakteri dalam suatu populasi besar sel bakteri yang terpapar antibakteri cukup sederhana. Bila dalam suatu populasi besar sel, ada beberapa sel serta genotip resisten (mempunyai sifat resisten terhadap obat), sel yang dapat tumbuh dalam lingkungan abiotik tersebut akan menghasilkan populasi baru yang sebagian besar merupakan genotip resisten. Timbulnya sedikit sel yang secara genotip resisten tersebut adalah akibat mutagenesis mikroba. Mekanisme biokimia resistensi bakteri terhadap antibiotik tertentu adalah dengan cara (1) penurunan permeabilitas terhadap antibiotik, (2) inaktivasi enzimatik antibiotik, (3) modifikasi sifat tempat reseptor obat, (4) peningkatan sintesis metabolit antagonis terhadap antibiotik (Shulman ST dkk., 1994).

Resistensi terhadap obat anti tuberkulosis (OAT) ada 3 macam yaitu (1) mutan yang resisten, di dalam setiap populasi bakteri tuberkulosis (TB) akan ada bakteri dalam jumlah kecil yang resisten secara alami. Apabila hanya satu jenis obat yang diberikan, bakteri TB yang sensitif akan dibasmi, tetapi bakteribakteri yang resisten akan berkembangbiak. Karena itu jangan pernah memberikan pengobatan dengan obat tunggal (monoterapi); (2) resistensi sekunder/resistensi yang diperoleh, hal ini dapat timbul karena pengobatan tidak benar, pemberian 2 macam obat dimana salah satu obat sudah resisten, pasien gagal minum obat secara benar; (3) resistensi primer, terjadi apabila seseorang ketularan oleh orang yang memiliki bakteri TB dengan resistensi yang diperoleh terhadap satu obat atau lebih (Crofton J dkk., 2002). Pada 
penelitian ini dari 13 sampel yang diamplifikasi, terdapat 4 (31\%) sampel resisten terhadap INH yang di tunjukkan dengan terputusnya pita amplifikasi gen ahpc (383 bp) , gen katG (296 bp) dan gen inhA (193 bp) bisa disebabkan karena terjadinya modifikasi sifat pada tempat reseptor obat/modifikasi pada daerah sasaran obat (mutasi), dan gagal mengikat INH.dan 9 (69\%) sampel sensitive terhadap INH yang ditunjukkan dengan adanya pita amplifikasi gen ahpc (383 bp) ,gen katG (296 bp) dan gen inhA (193 bp) bisa disebabkan oleh kecocokan obat/modifikasi pada daerah sasaran obat.

Untuk pemetaan munculnya MDR pada orang dengan resistensi primer, maka perlu dilakukan penelitian tentang sifat resistensi Mycobacterium tuberculosis dengan primer antibiotic lain.

\section{KESIMPULAN}

Dari hasil penelitian menunjukkan bahwa, dari 13 sampel yang diamplifikasi, didapatkan 4 (31\%) sampel sputum penderita Tuberkulosis yang baru memulai pengobatan resisten terhadap INH dan 9 (69\%) sampel sputum penderita Tuberkulosis yang baru memulai pengobatan sensitive terhadap INH dan terjadinya resistensi Mycobacterium tuberculosis terhadap INH dipengaruhi oleh mutasi pada beberapa gen, mutasi ini terutama terjadi pada gen katG, gen inhA, dan gen ahpC.

\section{SARAN}

Penelitian lebih lanjut di gunakan lebih banyak sampel untuk deteksi dini resistensi obat anti tuberculosis terhadap penderita tuberculosis.

\section{DAFTAR PUSTAKA}

Debbie S.retnoningrum, Roga F.kembaren, 2004. Mekanisme Tingkat Molekul Resistensi Terhadap Beberapa Obat pada Mycobacterium Tuberculosis. Acta Pharmaceutica Indonesia vol XXIX no 3, hal 92-95

Fatchiyah, Estri Laras Arumingtyas, Sri Widyanti, Sri Widyanti, Sri Rahayu, 2011. Biologi Molekuler Prinsip Dasar Analis. Penerbit Erlangga. Malang. hal 12-57

Kementerian Kesehatan Republik Indonesia, 2016. Data dan Informasi Kesehatan Profil Kesehatan Indonesia. Jakarta. hal 116

Kementerian Kesehatan RI, 2011. Pedoman Nasional Pengendalian TB. Kemenkes RI. Jakarta. hal 2026

Masriadi, 2017 . Epidemiologi Penyakit Menular. Bekasi : Raja Grafah Perada

Nofriyanda, 2010. Analisis Molekuler Pada Proses Resistensi Mikobakterium Tuberkulosis Terhadap Obat-Obat Anti Tuberkulosis (https://www.academia.edu/31464 74/MEKANISME_RESISTENSI_ OBAT_ANTI_TUBERKULOSIS) diakses pada tanggal 10 desember 2018.

Shulman ST: Phair JP : Sommers HM, 1994. Dasar Biologis dan Klinis Penyakit Infeksi. Edisi IV. Gajah Mada Universitas Presssis, diakses tanggal 18 November 2018

Syaifudin.M, Marialina.R, Harris.I, Budiman.B, 2006. Identifikasi Mycobacterium tuberculosis dan Analisis Mutasi Gen rpoB dan katG Penyebab Resistensi Ganda 
dengan Teknik Molekuler, Departemen Mikrobiologi, Fakultas Kedokteran, Universitas Indonesia 
Tabel 1 Data Hasil Pemeriksaan sputum penderita Tuberkulosis

\begin{tabular}{cccc}
\hline NO & SAMPEL & $\begin{array}{c}\text { HASIL } \\
\text { PEMERIKSAAN } \\
\text { KULTUR }\end{array}$ & HASIL PCR \\
\hline 1 & & Positif 4 & Sensitive \\
2 & A & Positif 4 & Sensitive \\
3 & C & Positif 4 & Resisten \\
4 & D & Positif 4 & Sensitive \\
5 & E & Positif 4 & Resisten \\
6 & F & Positif 1 & Sensitive \\
7 & G & Positif 3 & Resisten \\
8 & H & Positif 3 & Sensitive \\
9 & I & Positif 3 & Sensitive \\
10 & J & Positif 1 & Sensitive \\
11 & K & Positif 2 & Sensitive \\
12 & L & Positif 2 & Sensitive \\
13 & M & Positif 3 & Resisten \\
\hline
\end{tabular}

Pada pemeriksaan PCR dilakukan proses ekstraksi yang bertujuan untuk memisahkan DNA dari komponen sel lainnya. Untuk amplifikasi DNA menggunakan teknik PCR. Hasil dari amplifikasi DNA pada pasien yang baru memulai pengobatan adalah sebagai berikut

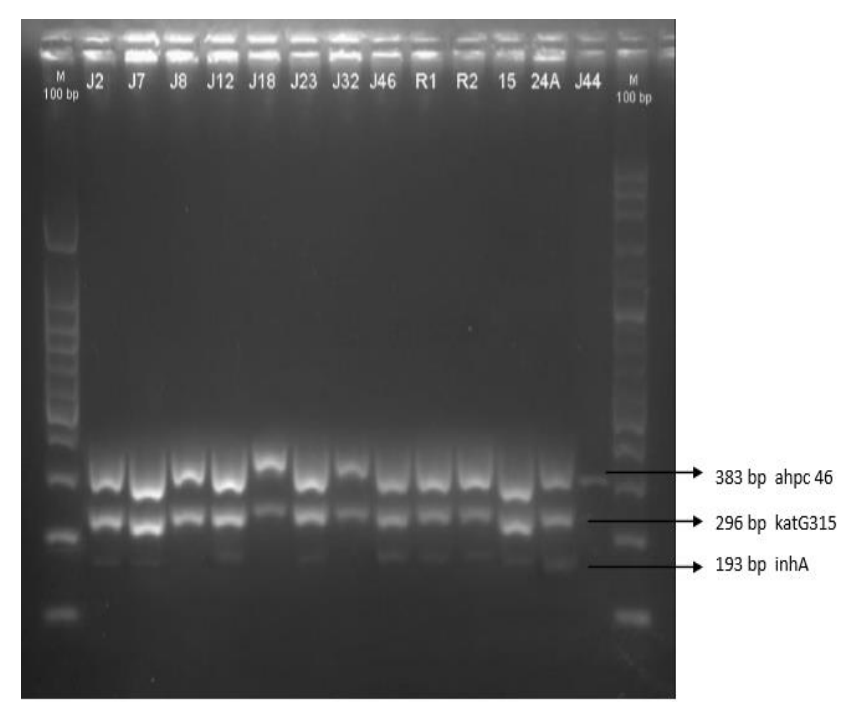

Gambar 1 : Hasil amplifkasi PCR specimen sputum yang di amplifikasi dengan primer katG 315 , ahpC46, inhA 


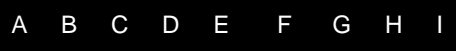

Keterangan :

- M Ladder 100 bp = Mycobacterium tuberculosis kontrol

- Sampel C,E,G,M = resisten terhadap INH

- Sampel A,B,D,F,H,I,J,K,L = sensitive terhadap INH

- Sampel C = Mutasi pada 296 bp dan 193 bp

- Sampel E = Mutasi pada 383 bp, 296 bp dan 193 bp

- Sampel G = Mutasi pada 383 bp, 296 bp dan 193 bp

- Sampel M = Mutasi pada 383 bp, 296 bp dan 193 bp 